\title{
IMPLICATIONS OF THE VARIABILITY IN SOIL PENETRATION RESISTANCE FOR STATISTICAL ANALYSIS $^{(1)}$
}

\author{
Paulo Ivonir Gubiani ${ }^{(2)}$, José Miguel Reichert ${ }^{(3)}$, Dalvan José \\ Reinert $^{(3)} \&$ Neiva Somavilla Gelain ${ }^{(4)}$
}

\begin{abstract}
SUMMARY
Soil penetration resistance $(P R)$ is a measure of soil compaction closely related to soil structure and plant growth. However, the variability in PR hampers the statistical analyses. This study aimed to evaluate the variability of soil PR on the efficiency of parametric and nonparametric analyses in indentifying significant effects of soil compaction and to classify the coefficient of variation of PR into low, medium, high and very high. On six dates, the PR of a typical dystrophic Red Ultisol under continuous no-tillage for 16 years was measured. Three tillage and/ or traffic conditions were established with the application of: (i) no chiseling or additional traffic, (ii) additional compaction, and (iii) chiseling. On each date, the nineteen PR data (measured at every $1.5 \mathrm{~cm}$ to a depth of $28.5 \mathrm{~cm}$ ) were grouped in layers with different thickness. In each layer, the treatment effects were evaluated by variance (ANOVA) and Kruskal-Wallis analyses in a completely randomized design, and the coefficients of variation of all analyses were classified (low, intermediate, high and very high). The ANOVA performed better in discriminating the compaction effects, but the rejection rate of null hypothesis decreased from 100 to $80 \%$ when the coefficient of variation increased from 15 to $26 \%$. The values of 15 and $26 \%$ were the thresholds separating the low/intermediate and the high/ very high coefficient variation classes of $P R$ in this Ultisol.
\end{abstract}

Index terms: compaction, coefficient of variation, normality.

\footnotetext{
(1) Received for publication in September 1, 2010 and approved in May 24, 2011.

${ }^{(2)}$ Doctoral student, Graduate Program in Soil Sciences (PPGCS), CAPES Scholarship. Federal University of Santa Maria UFSM. Campus Universitário, CEP 97105-900 Santa Maria (RS). E-mail: paulogubiani@gmail.com

(3) Professor at the Department of Soils - UFSM, CNPq researcher. E-mail: reichert@ufsm.br, dalvan@ufsm.br

${ }^{(4)}$ Master student, Graduate Program in Forestry Science, Federal University of Santa Maria - UFSM. REUNI-CAPES scholar. E-mail: neivaengenheira@gmail.com
} 


\title{
RESUMO: IMPLICAÇÃO DA VARIABILIDADE DA RESISTÊNCIA DO SOLO À PENETRAÇÃO NA ANÁLISE ESTATÍSTICA
}

\begin{abstract}
A resistência do solo à penetração é uma medida da sua compactação relacionada como crescimento das plantas, mas sua variabilidade dificulta a análise estatística. Os objetivos deste trabalho foram analisar a variabilidade da resistência do solo à penetração sobre a eficiência de testes paramétricos e não paramétricos na discriminação do efeito de níveis de compactação e classificar os coeficientes de variação da resistência do solo à penetração nas classes baixa, média, alta e muito alta. A resistência do solo à penetração foi medida em diferentes datas, em Argissolo Vermelho Distrófico típico sob semeadura direta por 16 anos, em três condições: (i) sem aplicação de tráfego adicional e escarificação, (ii) com aplicação de compactação adicional e (iii) com escarificação. Em cada data, 19 medidas de RP (feitas de o a 28,5 cm, a cada 1,5 cm) foram agrupadas para formar várias camadas com diferentes espessuras. Em cada camada, os efeitos de tratamentos foram avaliados pela análise de variância (ANOVA) e por Kruskal-Wallis, num delineamento inteiramente casualizado, sendo os coeficientes de variação de todas as análises classificados como baixo, médio, alto e muito alto. A ANOVA discriminou melhor os efeitos dos níveis de compactação, porém a taxa de rejeição da hipótese nula decresceu de 100 para $80 \%$ quando o coeficiente de variação aumentou de 15 para $26 \%$. Os valores de 15 e $26 \%$ definiram, respectivamente, os limites de separação das classes baixa / média e alta / muito alta para coeficientes de variação de RP do Argissolo estudado.
\end{abstract}

Termos de indexação: compactação, coeficiente de variação, normalidade.

\section{INTRODUCTION}

Soil penetration resistance $(\mathrm{PR})$ is a measure used to indicate the degree of soil compaction. Recent research efforts have emphasized the importance of PR in determining the critical compaction thresholds for plant growth (Tormena et al., 2007; Reichert et al., 2009). Thus, it is essential to use statistics that adequately represents the $\mathrm{PR}$ of a given soil in order to obtain consistent conclusions on soil treatments. When the objective is to evaluate PR in the layers of a profile, it is also important to identify layers in which the $P R$ variability is not very high, which could affect the ability of statistical tests to separate the treatments effects on PR.

When PR is measured in situ, a PR data set is obtained for soil profile. In this case, the statistical analysis is usually applied for each profile layer. Multivariate techniques can be used to detect contrasting layers (Weirich Neto et al., 2006), but in most cases they are arbitrarily defined or based on PR behavior changes in depth. Therefore, the choice of thicker or thinner layers may modify the statistical results and the study conclusions.

The mean of a layer/sample is one of the most commonly used statistics to represent the data set (Seco et al., 2004; Collares et al., 2006). The PR mean of each layer, of each experimental unit, are usually submitted to variance and means comparison analyses, in which the least significant difference is represented by lines along the PR profiles.
The mean, maximum and median were the statistics that identified soil use and management effects on PR most clearly by variance analysis in the study of Leão \& Silva (2006). These authors suggested the use of means as the most appropriate statistic to represent a soil sample and the effects of soil use and management. But, apart from identifying the best statistical method for variance analysis, the assumptions required for analysis should also be assessed. These aspects are less discussed in soil analysis (Mesquita et al., 2003), particularly regarding the application of nonparametric analysis, when the data distribution is not normal.

Another aspect that has not been studied is the effect of non-controlled intrinsic variability of PR on the efficiency of variance analysis. The PR variability has often been correlated to spatial (Utset \& Cid, 2001; Silva et al., 2004; Souza, et al., 2006) and temporal changes (Genro Junior et al., 2004; Lapen et al., 2004). However, the non-controlled variability affects both the test performance used for data analysis and the planning of the experimental design (Stork et al., 2004).

The variability of a property and the experimental accuracy can be evaluated by the coefficient of variation (CV) (Pimentel Gomes, 1990); this author proposed a widely used classification for the CV. However, the high or low rank of the CV of a given variable is not necessarily the same for another variable (Costa et al., 2008).

Some methodologies have been suggested to classify the $\mathrm{CV}$ for a given variable. The methodology proposed 
by Garcia (1989) is only applicable if the CV distribution is normal, while Costa et al. (2002) suggested a procedure that is applicable regardless of the distribution of the CV, especially for non-normal distribution. Some application examples are the studies of Amaral et al. (1997) for plant properties, Judice et al. (1999) in studies with swine, and Costa et al. (2008) for soil moisture experiments. However, there are many opportunities and needs for the application of these methodologies in soil research, which would improve the experimental planning and provide criteria for the classification of variability and underlie coherent comparisons of results from different experiments.

The objectives of this study were to: (i) analyze the deviation of PR distribution from normal distribution; (ii) verify the effectiveness of parametric (ANOVA) and nonparametric (Kruskal-Wallis) analyses in the identification of significant effects of soil compaction treatments on PR; and (iii) classify the PR coefficient of variation, according to Costa (2002).

\section{MATERIAL AND METHODS}

The data of this study were extracted from an experiment on a clayey Dystrophic Red Ultisol (Argissolo Vermelho Distrófico) in Santa Maria, RS (29 $43^{\prime} 14^{\prime \prime} \mathrm{S}, 53^{\circ} 42^{\prime} 18^{\prime \prime} \mathrm{W}: 95 \mathrm{~m}$ asl), in 2008 , to evaluate the effect of traffic and chiseling on no-tillage soil, under black bean. The treatments consisted of: (1) NT - soil under no-tillage for 16 years, (2) NTCo soil under no-tillage for 16 years with additional compaction (four wellings of a farm tractor with a mass of $3.8 \mathrm{Mg}$ ) and (3) NTCh - soil under no-tillage for 16 years with chiseling to the depth of $30 \mathrm{~cm}$. The experimental design used in the analyses was entirely randomized with eight replications, resulting in 24 plots.

The PR was measured on February 20, 22, 24, 25, and March 05 and 06, 2008. In this period, the soil moisture varied from 0.10 to $0.24 \mathrm{~cm}^{3} \mathrm{~cm}^{-3}$. The PR was measured using an ultrasonic cone penetrometer, with electronic data storage and a conical tip with an angle of $30^{\circ}$ and $12.83 \mathrm{~mm}$ base diameter. The penetration rate was approximately $2 \mathrm{~m} \mathrm{~min}^{-1}$ and data were recorded at depth intervals of $1.5 \mathrm{~cm}$. On each date, the PR was measured at five points in the bean interrow. At each of these points, 19 measures were obtained (at intervals of $1.5 \mathrm{~cm}$ ) down to a depth of $28.5 \mathrm{~cm}$ in the soil profile. In total, a data set was generated with $13,680 \mathrm{PR}$ measurements (24 plots $\mathrm{x}$ 5 PR profiles per plot x 19 PR measurements x 6 dates).

The PR profile was divided into layers with different thickness (Figure 1). The PR of each layer was represented by the mean value, as suggested by Leão \& Silva (2006). The establishment of these layers does not introduce effects by granulometric differences, because the texture of the entire soil layer considered in this study $(0-28.5 \mathrm{~cm})$ is homogeneous $\left(150 \mathrm{~g} \mathrm{~kg}^{-1}\right.$ of clay, $238 \mathrm{~g} \mathrm{~kg}^{-1}$ of silt and $612 \mathrm{~g} \mathrm{~kg}^{-1}$ of sand).

For each of the 19 profile layers, the treatment effect on asymmetry and the normal probability of the PR measurements were assessed separately for each date based on the significance of the ShapiroWilk test (SAS, 1999). For each analysis, the data set was $\mathrm{N}=40$, consisting of $5 \mathrm{PR}$ measurements per plot $\mathrm{x} 8$ plots. In total, 342 analyses $(6$ dates $\mathrm{x} 3$ compaction levels $\mathrm{x} 19$ layers) were conducted to determine the effect of soil structural conditions on the PR distribution in relation to the normal distribution curve, with no intention of examining the relationships between treatments and soil layers.

For all layers and dates in which the PR was measured, the compaction effect on RP was assessed by ANOVA and the Kruskal-Wallis analysis, which is the nonparametric analysis equivalent to ANOVA (SAS, 1999), applicable when the design is entirely randomized (Storck et al., 2004). The number of observations of each analysis was $\mathrm{N}=24$ (one value per plot, represented by the mean PR value of the five PR measurements of the analyzed layer).

The analysis efficiency was evaluated by the rejection rate of the null hypothesis $\left(\mathrm{H}_{0}\right)$, assuming non-significance of the treatment effects at $\alpha=0.05$.

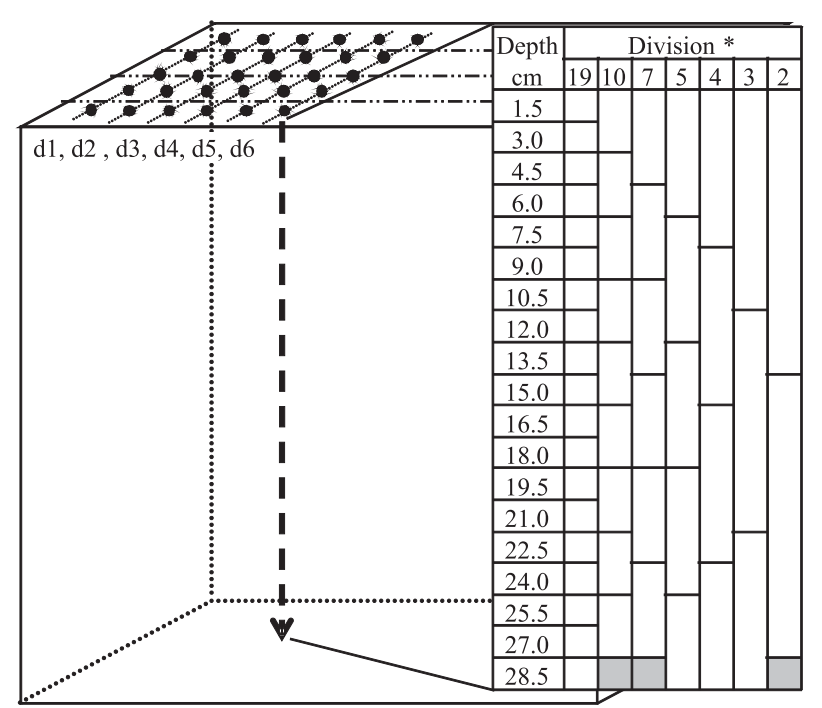

Figure 1. Schematic experimental unit with distribution of PR measurements (points are in perpendicular direction to the planting rows), and the divisions of $P R$ profile in layers. $d 1, d 2$, $\mathrm{d} 3, \mathrm{~d} 4, \mathrm{~d} 5$, and $\mathrm{d} 6$ that refer to the measurements on the following dates, respectively: Feb 20, 22, 24, and 25 and Mar 5 and $6 . *$ In some divisions $(3,4$ and 5$)$ the deeper layers were less thick; data of grayish mottled regions were not included in the analyses. 
Therefore, the analysis that most rejected $\mathrm{H}_{0}$ would be most adequate to discriminate the treatment effects.

The rejection rate of $\mathrm{H}_{0}$ in ANOVA was also related to the estimate of the experimental CV to determine the influence of $\mathrm{CV}$ on the discrimination ability of ANOVA for compaction effects. The estimated experimental CV was obtained from 300 variance analyses, using the formula $\mathrm{CV}(\%)=\sqrt{\mathrm{MSE}} / \overline{\mathrm{M}}$; where MSE is the mean square error and $\bar{M}$ the mean estimate.

The $300 \mathrm{CV}$ were arranged in ascending order, and the rejection rate of $\mathrm{H}_{0}\left(\mathrm{RRH}_{0}\right)$ was calculated as follows: $\mathrm{RRH}_{0 \mathrm{j}}=100\left(\sum_{\mathrm{i}=0}^{\mathrm{k}} \mathrm{RH}_{0 \mathrm{i}}\right) / \mathrm{k}$; where $\mathrm{i}=1,2,3, \ldots$, $\mathrm{n} ; \mathrm{k}=\mathrm{j}=1,2,3, \ldots, \mathrm{n} ; \mathrm{RH}_{0 \mathrm{i}}$ is the $\mathrm{i}^{\text {th }}$ occurrence of $\mathrm{H}_{0}$ rejection. The $\mathrm{RRH}_{0 \mathrm{i}}$ values were related to the respective $C_{j}$. The effect of the $P R$ profile segmentation on $\mathrm{CV}$ values was also evaluated.

In order to classify the CV values, the methodology proposed by Costa et al (2002) was used, which is applicable regardless of the data distribution. The method is based on the median $(\mathrm{Md}=(\mathrm{Q} 1+\mathrm{Q} 3) / 2)$, where Q1 and Q3 are the first and third quartiles, respectively, and on the pseudo-sigma ( $\mathrm{PS}=\mathrm{IQR} / 1.35)$, where IQR is the interquartile range (Q3-Q1).
According to Costa et al (2002), the pseudo-sigma corresponds to the standard deviation that a normal distribution might have to produce the same interquartile distance: for that reason; therefore, the 1.35 factor is introduced in the IQR formula. According to the authors, the pseudo-sigma is a more resistant dispersion measure than standard deviation; pseudo-sigma tends to standard deviation if the distribution is close to normal.

Using the classification proposed by Costa et al. (2002), the CV determined for the data of this study were classified as low: $\mathrm{CV} \leq(\mathrm{Md}-\mathrm{PS})$; intermediate: $(\mathrm{Md}-\mathrm{PS})<\mathrm{CV} \leq(\mathrm{Md}+\mathrm{PS})$; high: $(\mathrm{Md}+\mathrm{PS})<\mathrm{CV} \leq$ $(\mathrm{Md}+2 \mathrm{PS})$ and very high: $\mathrm{CV}>(\mathrm{Md}+2 \mathrm{PS})$. The results were compared with generally accepted values used for CV classification.

\section{RESULTS}

The exploratory analyses of the 19 soil layers, defined by each PR profile measurement, indicated that the asymmetry is predominantly on the right side for chiseled no-tillage soil (NTCh) (Figure 2). Under no-tillage (NT) and no-tillage with additional compaction (NTCo), the asymmetry was similar on
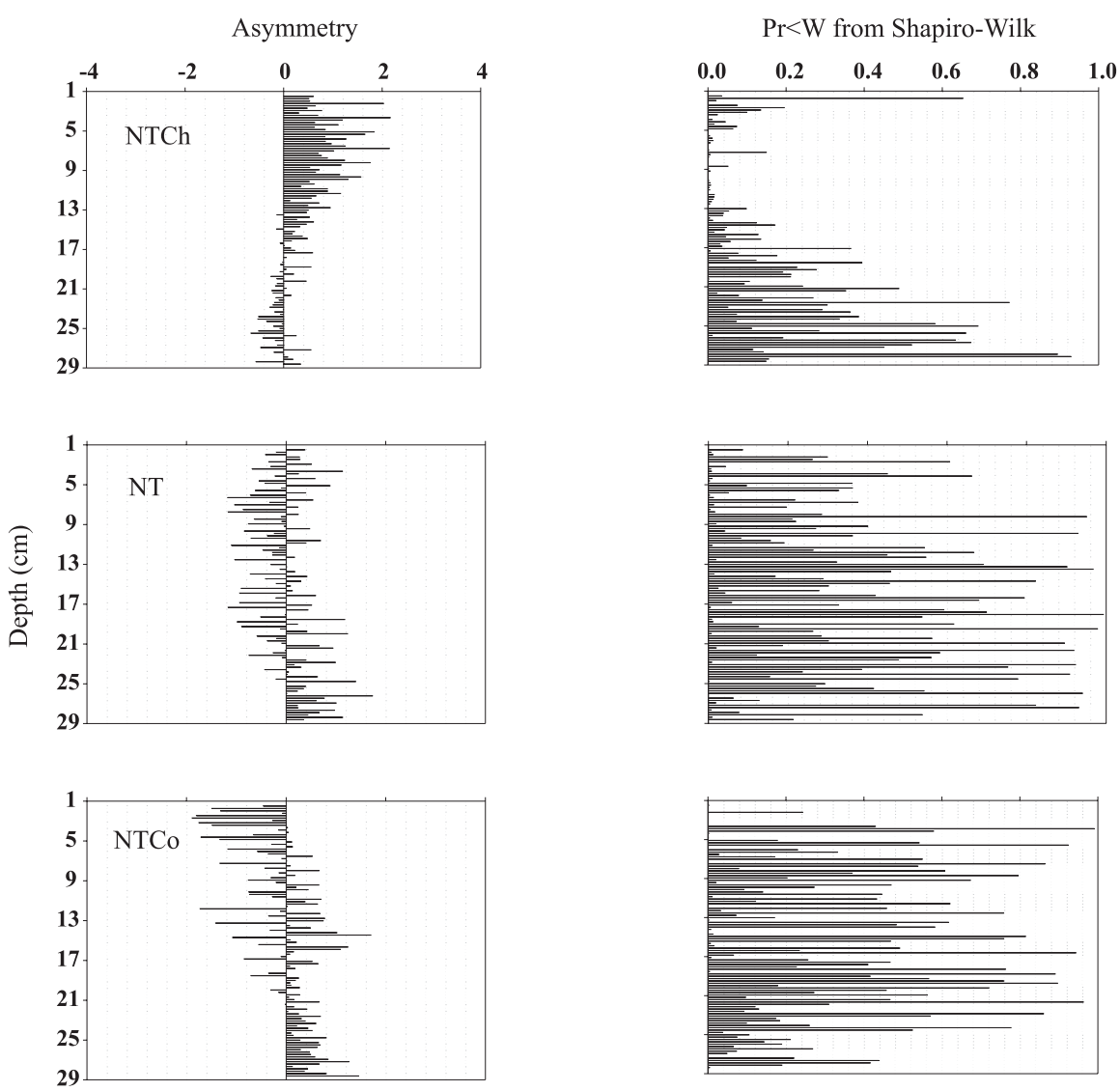

Figure 2. Indicators of normal distribution of penetration resistance at different compaction levels and in soil layers. NTCh: no-tillage with chiseling; NT: no-tillage; NTCo: no-tillage with compaction. 
the left and right side. A proportion of 85,89 and $83 \%$ of the asymmetries in NTCh, NT and NTCo, respectively, was within the range of -1 and 1 (typical interval of normal distribution). Therefore, in 15, 11 and $17 \%$ of the asymmetry values the mean is not the measure that best represents the observation set.

The Shapiro-Wilk test indicated normal data distribution in 53, 73 and $73 \%$ of the analyses for NTCh, NT and NTCo, respectively. Thus, in NTCh, slightly more than half of the data sets were adequately represented by the mean value.

In the analyses to evaluate the effect of compaction levels on PR in the established soil layers, the ANOVA produced the highest rejection rate of the null hypothesis (Table 1). The efficiency of both analyses decreased as the number of PR values grouped on a given layer increased, while the proportion of ShapiroWilk significant results was little affected.

The ANOVA indicated significance for the hypothesis of differences in PR between the compaction levels in $100 \%$ of the analysis when the data set consisted only of results from analyses in which the CV were lower than $15 \%$ (Figure 3a). The percentage of significance decreased sharply and linearly with the proportion of analyses in which the CV was higher than $15 \%$. This tendency persisted when the analyses of the CV with values up to nearly $30 \%$ were included. In that range, the significance decreased from 100 to $80 \%$. The percentage of significance remained at around $80 \%$, even when analyses with CV higher than $30 \%$ were included.

The segmentation of the PR profile caused a slight increase of the CV (Figure 3b). However, the mean and median of the CV of each layer did not change significantly even when the PR profile was separated in 19 layers.

Descriptive analysis of the CV indicated that the mean and median were similar, suggesting that the CV distribution was close to normal (Figure 2). However, the Shapiro-Wilk test rejected the normality hypothesis, indicating that the CV classification by the technique proposed by Costa et al. (2002) is more adequate than the classification by techniques based on normal distribution (Garcia, 1999). The classification of Costa et al. (2002) indicated that the variability is low if the $\mathrm{CV}$ is lower than $15 \%$ and very high for $\mathrm{CV}$ if higher than $26 \%$ (Table 2 ).

Table 1. Discrimination of the effects of compaction levels on penetration resistance (PR) by ANOVA and Kruskal-Wallis analyses

\begin{tabular}{ccccc}
\hline $\begin{array}{c}\text { PR profile } \\
\text { division }\end{array}$ & $\begin{array}{c}\text { Layers } \\
\text { formed in } \\
\text { each division }\end{array}$ & $\begin{array}{c}\text { RP measures } \\
\text { grouped in } \\
\text { each layer }\end{array}$ & $\begin{array}{c}\text { Rejection percentage of null } \\
\text { hypothesis }\end{array}$ & $\begin{array}{c}\text { Normality percentage of } \\
\text { Shapiro-Wilk }\end{array}$ \\
\end{tabular}

\begin{tabular}{|c|c|c|c|c|c|}
\hline 0 & 19 & 1 & 91 & 85 & 57 \\
\hline 1 & 10 & 2 & 75 & 67 & 56 \\
\hline 2 & 7 & 3 & 76 & 64 & 60 \\
\hline 3 & 5 & 4 & 73 & 67 & 57 \\
\hline 4 & 4 & 5 & 75 & 71 & 54 \\
\hline 5 & 3 & 7 & 72 & 71 & 56 \\
\hline 6 & 2 & 9 & 67 & 56 & 61 \\
\hline
\end{tabular}

(1) PR profile measurements, grouped to compose the analysis layer (see Figure 1 ). ${ }^{(2)}$ The significance level analyses was $\alpha=0.05$.
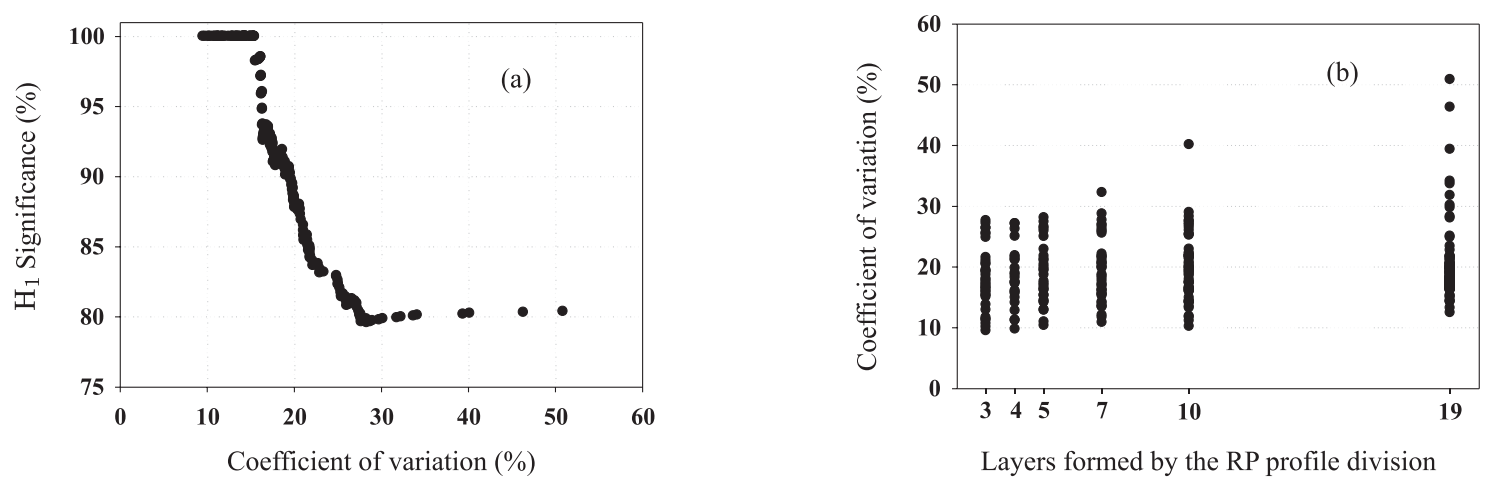

Figure 3. Relationship between the coefficient of variation and the significance of the hypothesis of differences in penetration resistance $\left(\mathrm{H}_{1}\right)$ between compaction levels $(\mathrm{a})$ and the effect of PR profile division on the coefficient of variation (b). 
Table 2. Statistics and classification of the PR coefficients of variation

\begin{tabular}{lcl}
\hline Statistic $^{(1)}$ & Value & CV classification \\
\hline Q3 & 21.29 & Low \\
Q1 & 16.34 & CV $<=15$ \\
IQR & 4.95 & \\
Median & 18.25 & Intermediate \\
N & 306 & $15<\mathrm{CV}<=22$ \\
Mean & 19.32 & \\
Pseudo-sigma & 3.67 & High \\
Maximum & 50.84 & $22<\mathrm{CV}<=26$ \\
Minimum & 9.51 & \\
Amplitude & 41.34 & Very high \\
Shapiro-Wilk & $\mathrm{W}=0.89(\mathrm{Pr}<\mathrm{W}=<0.001)$ & $\mathrm{CV}>26$ \\
\hline
\end{tabular}

(1) Q1 and Q3 are the first and third quartiles, respectively; $\mathrm{IQR}$ is the interquartile range (Q3 - Q1), and $\mathrm{N}$ is the sample size.

\section{DISCUSSION}

The asymmetry coefficient indicated that the PR distribution was modified as a consequence of soil structure changes, since $15 \%$ of the asymmetry values in NTCh and $17 \%$ in NTCo were outside the range -1 to 1 , against $11 \%$ in NT. These results indicate that the mean would not be the statistics that best represents the set of observations.

After chiseling, the soil structure normally shows spatial zones with high and low structural modification. The sites without tillage represented a relatively smaller soil volume than the tilled sites and accounted for the highest PR values that caused asymmetry to the right and increased the mean PR value (Figure 2). As a practical consequence, the use of the mean to represent the PR of a chiseled soil overestimates the PR of most of the soil volume explored by roots, because they preferentially grow through soil of low mechanical resistance (Martino \& Shaykewich, 1994; Clark et al., 2003).

In compacted soil, the proportion of asymmetry values between -1 and 1 was $50 \%$ higher on the left than the right. In this case, the soil volume compacted by repeated wheeling was higher than the proportion of soil under less intense compaction, which caused asymmetry to the left and reduced the mean $P R$ value. Thus, in trafficked plots, the PR mean better represent the soil zones in which root density is high (preferential paths with low resistant for root growth).

Besides the aspects related to asymmetry, care must be taken in applications of the parametric analyses, particularly for data from chiseled soil, since the Shapiro-Wilk test normality proportion for the measured PR data was only $53 \%$. However, when data with normal distribution, from soils without or with little structure changes, are included in the data of chiseled or compacted treatments, the total normality proportion increases. As a result, ANOVA performance is improved, because it is a robust analysis, i.e., moderate deviations from the model assumptions do not affect the result very much (Stork et al., 2004).

The highest proportion of significance for ANOVA, for the hypothesis of difference between the compaction levels, shows the ability of the analysis to discriminate effects even in the case of deviation from the normal distribution (Table 1). Although only $57 \%$ of the analyzed sets had normal distribution, $91 \%$ of the results were significant when the PR profile was divided in 19 layers (Table 1). In all cases, the significance percentage was higher for ANOVA than for Kruskal-Wallis analysis, suggesting that the latter would only be advantageous if ANOVA was greatly affected by data distribution.

Although the Kruskal-Wallis analysis does not require assumptions on data distribution, the observations in each group are assumed to result from populations with the same distribution shape (McDonald, 2009). This author states that, if different groups have different distribution shapes (e.g., some are asymmetric to the left and others to the right or have different variances), the Kruskal-Wallis analysis may not produce accurate results. The differences in the asymmetry of the PR data for NTCh and NTCo (Figure 2) can be the main cause for the decreasing proportion of significant effects in the Kruskal-Wallis analysis (Table 1).

The decreasing significance for the hypothesis of differences between the compaction levels with the increasing number of PR measurements grouped in the same layer (Table 1) may be explained by the soil structure characteristics due the position of the layers in the profile. When the layer thickness increases, all layers are shifted to deeper positions, where the effects of changes in soil structure on PR (particularly additional compaction applied to the topsoil) decrease, reducing the significance for the hypothesis of differences between the compaction levels. This interpretation seems reasonable because the data distribution pattern in relation to normality was not affected. Therefore, for PR profiles similar to those in this study, data grouping into a few layers discriminates less clearly the effects of soil structural changes on the PR.

The CV affected the significance of the $\mathrm{F}$ test of ANOVA, due to its direct relation with the experimental error. Since CV is the square root of the experimental error in percentage of the mean, which corresponds to the percentage of standard deviation from the mean (Pimentel Gomes, 1990), any factor that increases the experimental error or the non-controlled variability also increases the CV and reduces the significance of the F test, as emphasized by Stork et al. (2004) and evidenced in this study (Figure 3).

Changes in soil moisture and bulk density are indicated as the main causes of $\mathrm{PR}$ variation. At a given site, the $\mathrm{CV}$ values may range from 7 to $80 \%$ 
due to the heterogeneity of soil moisture (Utset \& Cid, 2001). In Oxisols, Tormena et al. (2007) found CV values of 41 to $96 \%$, when the PR data of samples with bulk density between 1.01 and $1.34 \mathrm{~g} \mathrm{~cm}^{-3}$ and moistures between 0.26 and $0.53 \mathrm{~cm}^{3} \mathrm{~cm}^{-3}$ were evaluated. Kaiser et al. (2009) reported lower values of CV (28\%), also with PR data (840-3.080 kPa) for another Oxisol with bulk densities varying from 1.14 to $1.41 \mathrm{~g} \mathrm{~cm}^{-3}$ and moistures from 0.21 to $0.41 \mathrm{~cm}^{3} \mathrm{~cm}^{-3}$.

The class limits for the CV resulting from the application of the technique proposed by Costa et al. (2002) (Table 2) were consistent with the significance response of the $\mathrm{F}$ test (Figure 3). The $\mathrm{CV}$ upper threshold of the low class (15\%) and lower threshold of the very high class (26\%) were similar to the values that identify the highest and lowest significance points of the F test, respectively. These values are close to the general classification values of Pimentel Gomes (1990), with thresholds of 10 and $30 \%$, for the low and very high classes, respectively.

Based on the above data of Tormena et al. (2007), there is an indication that the CV classification for the PR in Oxisol may result in class limits higher than those obtained for the Ultisol of this study. The analyses of this study incorporate 11,400 PR data, ranging from 35 to $4,189 \mathrm{kPa}$, of soil with bulk densities ranging from 1.43 to $1.82 \mathrm{~g} \mathrm{~cm}^{-3}$ and moistures from 0.10 to $0.24 \mathrm{~cm}^{3} \mathrm{~cm}^{-3}$, resulting in CV between 9.5 and $50.8 \%$ (Figure 2). These moisture and bulk density ranges and the large database allow the conclusion that the $\mathrm{CV}$ values obtained in this study are representative of the CV population of the soil layer evaluated.

The experimental design, however, influences the estimation of the mean square error (MSE) and consequently of $\mathrm{CV}$, an important factor to be considered when the number of treatments is high (Costa et al., 2002). The authors found that the CV class thresholds for experiments performed in a completely randomized design were usually lower than those in randomized blocks. These authors concluded the large number of treatments (up to 29) of the randomized blocks design as one of the reasons, which greatly increased the area of each block and raised the experimental error and the CV. Since more treatments than five are rarely used in soil experiments to evaluate $\mathrm{PR}$, the type of design interferes less with the estimation of CV evaluation. Consequently, the classification presented in this study can be used as a reference for the experimental design and interpretation of PR data of surface horizons of Ultisols.

\section{CONCLUSIONS}

1. Changes in soil structure increase the deviation of the distribution of penetration resistance in relation to the normal curve. The mean represents penetration resistance better in compacted than in chiseled soil.

2 . The reduction in the number of generated layers for analyzing the penetration resistance soil profile decrease the significance for the hypothesis of difference between soil treatments.

3. The increase of the experimental coefficient of variation of soil penetration resistance affects the ANOVA performance.

\section{LITERATURE CITED}

AMARAL, A.M.; MUNIZ, J.A. \& SOUZA, M. Avaliação do coeficiente de variação como medida da precisão na experimentação com citros. Pesq. Agropec. Bras., 32:12211225, 1997.

COLLARES, G.L.; REINERT, D.J.; REICHERT, J.M. \& KAISER, D.R. Qualidade física do solo na produtividade da cultura do feijoeiro num Argissolo. Pesq. Agropec. Bras., 41:1663-1674, 2006.

COSTA, F.M.; OLIVEIRA, J.M.; GUIMARÃES, E.C. \& TAVARES, M. Classificação do coeficiente de variação da umidade do solo em experimentação agrícola. FAMAT R., 10: 2008. Disponível em: http://www.portal.famat.ufu.br/ sites/famat.ufu.br/files/Anexos/Bookpage/ Famat_revista_artigo_04.pdf)

COSTA, N.H.A.D.; SERAPHIN, J.C. \& ZIMMERMANN, F.J.P Novo método de classificação de coeficientes de variação para a cultura do arroz de terras altas. Pesq. Agropec. Bras., 37:243-249, 2002.

CLARK, L.J.; WHALLEY, W.R. \& BARRACLOUGH, P.B. How do roots penetrate strong soil?. Plant Soil, 255:93-104, 2003.

GARCIA, C.H. Tabelas para classificação do coeficiente de variação. Piracicaba: IPEF, 1989. 12p. (Circular técnica, 171)

GENRO JUNIOR, S.A.; REINERT, D.J. \& REICHERT, J.M Variabilidade temporal da resistência à penetração de um Latossolo argiloso sob semeadura direta com rotação de culturas. R. Bras.Ci. Solo, 28:477-484, 2004.

JUDICE, M.G.; MINIZ, J.A. \& CARVALHEIRO, R. Avaliação do coeficiente de variação na experimentação com suínos. Ci. Agrotecnol., 23:170-173, 1999.

KAISER, D.R.; REINERT, D.J.; REICHERT, J.M.; COLLARES, G.L. \& KUNZ, M. Intervalo hídrico ótimo no perfil explorado pelas raízes de feijoeiro em um Latossolo sob diferentes níveis de compactação. R. Bras.Ci. Solo, 33:845856,2009

LAPEN, D.R.; TOPP, G.C.; EDWARDS, M.E.; GREGORICH, E.G. \& CURNOE, W.E. Combination cone penetration resistance/water content instrumentation to evaluate cone penetration-water content relationships in tillage research. Soil Tillage Res., 79:51-62, 2004. 
LEÃO, T.P. \& SILVA, A.P. A statistical basis for selecting parameters for the evaluation of soil penetration resistance. Sci. Agric., 63:552-557, 2006.

MARTINO, D. \& SHAYKEWICH, C.F. Root penetration profiles of wheat and barley as affected by soil penetration resistance in field conditions. Can. J. Soil Sci., 74:193200, 1994.

MCDONALD, J.H. Handbook of biological statistics (online version). 2.ed. Sparky House Publishing. Baltimore, 2009. p.319. Available at: http://www.lulu.com/product/ download/handbook-of-biological-statistics/5507348, Accessed: 18 Feb. 2010.

MESQUiTA, M.G.B.F.; MORAES, S.O. \& CORRENTE, J.E. Caracterização estatística de variáveis físicas do solo. Acta Sci. Agron., 25:35-44, 2003

PIMENTEL GOMES, F. Curso de estatística experimental. 12.ed. Piracicaba, Nobel, 1990. 467p.

REICHERT, J.M.; SUZUKI, L.E.A.S.; REINERT, D.J.; HORN, R. \& HAKANSSON, I. Reference bulk density and critical degree-of-compactness for no-till crop production in subtropical highly weathered soils. Soil Tillage Res., 102:242-254, 2009.

SAS Institute. SAS/STAT procedure guide for personal computers. 5.ed. Cary, 1999.

SECCO, D.; REINERT, D.J.; REICHERT, J.M. \& ROS, C.O. Produtividade de soja e propriedades físicas de um Latossolo submetido a sistemas de manejo e compactação. R. Bras.Ci. Solo, 28:797-804, 2004.
SILVA, V.R.; REICHERT, J.M. \& REINERT, D.J. Variabilidade espacial da resistência do solo à penetração em plantio direto. Ci. Rural, 34:399-406, 2004.

SOUZA, Z.M.; CAMPOS, M.C.C.; CAVALCANTE, I.H.L.; MARQUES JÚNIOR, J.; CESARIN, L.G. \& SOUZA S.R. Dependência espacial da resistência do solo à penetração e do teor de água do solo sob cultivo contínuo de cana-deaçúcar. Ci. Rural, 36:128-134, 2006.

STORK, L.; LOPES, S.J. \& LÚCIO, A.D. Experimentação II. 3.ed. Santa Maria, Universidade Federal de Santa Maria, 2004. 207p.

TORMENA, C.A.; ARAÚJO, M.A.; FIDALSKI, J. \& COSTA, J.M. Variação temporal do intervalo hídrico ótimo de um Latossolo Vermelho distroférrico sob sistemas de plantio direto. R. Bras.Ci. Solo, 31:211-219, 2007.

UTSET, A. \& CID, G. Soil penetrometer resistance spatial variability in a Ferrosol at several soil moisture conditions. Soil Tillage Res., 61:193-202, 2001.

WEIRICH NETO, P.H.; BORGHI, E.; SVERZUT, C.B.; MANTOVANI, E.C.; GOMIDE, R.L. \& NEWES, W.L.C. Análise multivariada da resistência do solo à penetração sob plantio direto. Ci. Rural, 36:1186-1192, 2006. 